\title{
Curiosity and the Path Forward
}

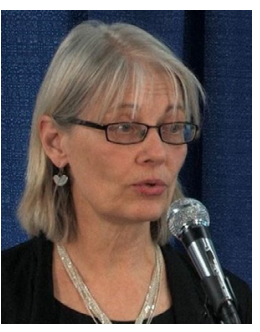

I believe that curiosity is one of our super powers. In my undergraduate class focused on sustainable food systems, we follow an inquirybased model and

identify a topic, then create a series of questions that we try to answer to find a path forward in the food system. Our latest topic was the new plant-based and cell-based meat substitutes.

The students' curiosity led them to logical and valuable questions. Were the new meats more ecologically sustainable? Nutritionally equal to meat? Healthy? Affordable? Accessible for everyone? Fundamentally, were these new products better to create a future world that allows us to "live in harmony with nature," which is the vision of the UN Global Biodiversity Framework ${ }^{1}$, while also meeting our social, health, and economic needs?

One third of the class had already tried new plant-based products, with reactions ranging from unimpressed to acceptable, indicating their curiosity led to a purchasing decision. Potential market opportunity does drive investments into the path forward. A recent report suggests that the U.S. plant-based food market will reach $\$ 10.7$ billion by $2027^{2}$, and the global investment specifically in labgrown meat drew six-fold in 2020.

My students' curiosity is also reflected in the conversations by many others. Within the business arena, specific questions about the new labgrown meats were featured in a Forbes article titled "What Questions Should We Be Asking About Cell-Based Meats?"4 Broader questions about how investments shape the path in food production and food systems, especially the underinvestment in agroecology, which is recognized as a sustainable path, have been the topic of webinars and a recent International Panel of Experts on Sustainable Food Systems publication.

As food and nutrition educators and leaders in behavior change, we often are responding to the food system but recognize that now is our time to have an active voice in shaping the food system and considering the often divergent paths forward. As theories shape our practice, there are emerging models that can help us direct our curiosity and conversations.

The discussions leading up to the UN Food Systems Summit 2021, a discussion starter document included these 10 elements to consider in designing nature-positive food production systems, and we are using this as a guide in my class discussions. ${ }^{6}$ The 10 elements include diversification, co-creation and sharing of knowledge, synergies, efficiency, recycling, resilience, human and social values, culture and food traditions, responsible governance, and circular and solidarity economy.

These elements may provide a roadmap for our curiosity and potential checklist as we consider our path forward. These may also help our discussions within local communities, because a resilient and sustainable future is lived locally, while recognizing the global repercussions of our food patterns.

The curiosity within our class was exciting and empowering as we look for answers and take action. For those who might be curious, the conclusion from my class about plant-based meats is that we need access to much more information to make a decision, and we would proceed with caution and moderation.
Jasia (Jayne) Steinmetz

$R D, C D$

President, Society for Nutrition

Education and Behavior

\section{REFERENCES}

1. UN Convention on Biological Diversity. Report of the Open-ended Working Group on the Post-2020 Global Biodiversity Framework on its Third Meeting (Part 1). UN Environment Programme; 2021. https://www.cbd.int/article/draft-1global-biodiversity-framework Accessed October 12, 2021.

2. Iannuzzi J, Faulds Z, Levick K. From Oatly to Odd Burger - the rise of plantbased food stocks in 2021. The Street. https://www.thestreet.com/investing/ plant-based-food-stocks-2021. Accessed October 12, 2021.

3. Carrington D. Lab-grown meat firms attract sixfold increase in investment. The Guardian. May 11, 2021. https:// www.theguardian.com/environment/ 2021/may/11/lab-grown-meat-companies-swallow-record-investments Accessed October 12, 2021.

4. Schweizer E. What questions should we be asking about cell-based meats? Forbes. May 6, 2021. https://www.forbes.com/ sites/errolschweizer/2021/05/06/whatquestions-should-we-be-asking-aboutcell-based-meats $/$ ? sh $=14$ f306486244 Accessed October 12, 2021.

5. Biovision Foundation for Ecological Development \& IPES-Food. Money Flows: What is Holding Back Investment in Agroecological Research for Africa? Biovision Foundation for Ecological Development \& International Panel of Experts on Sustainable Food Systems; 2020.

6. United Nations Food Systems Summit 2021. Discussion Starter Action Track 3: Boost Nature-Positive Food Production at Scale. United Nations; 2020. https:// www.un.org/sites/un2.un.org/files/unfssat3-discussion_starter-dec2020.pdf. 